\title{
Pemberdayaan Desa Melalui Program Pengembangan Perpustakaan Desa, Pendidikan Desa, dan Sosialisasi Pendidikan Tinggi
}

\author{
Alfa Julia ${ }^{1}$, Novadilah Amilatus Solikha ${ }^{2}$, Lula Salsabila ${ }^{3}$, \\ Ifah Amilatul Kharisma ${ }^{4}$, Annisa Aulia ${ }^{5}$ \\ 1,2,3,4,5 Universitas PGRI Wiranegara \\ email : alfajulia9@gmail.com¹, novadilaam04@gmail.com², lula.salsabila311@gmail.com³ \\ ifaamilatul2@gmail.com ${ }^{4}$, annisaauliaa0@gmail.com ${ }^{5}$
}

\begin{abstract}
The Covid-19 pandemic has occupied many activities in this world, such as the cessation of the face-to-face learning process and then according to the Circular Letter of the Minister of Education and Culture Number 4 of 2021 requiring all schools to learn online. Many students have difficulty in receiving material that is carried out online by their respective teachers and parents do not support learning activities from home. In KKN-DR, PGRI Wiranegara University students provide solutions in the form of developing a library by cleaning and rearranging library rooms, providing study guidance to students in the Sekargadung sub-district, and providing information related to universities that only require affordable fees so that they can continue their education to the next level.
\end{abstract}

Keywords: libraries, education, college.

\begin{abstract}
Abstrak
Pandemi Covid-19 telah menyita banyak kegiatan di dunia ini, seperti terhentinya proses pembelajaran secara tatap muka kemudian sesuai Surat Edaran Mendikbud Nomor 4 Tahun 2021 mengharuskan semua sekolah untuk belajar dalam jaringan. Banyak pelajar yang kesusahan dalam menerima materi yang diakukan melalui daring oleh guru mereka masingmasing dan orang tua kurang mendukung adanya kegiatan pembelajaran dari rumah. Dalam KKN-DR mahasiswa Universitas PGRI Wiranegara memberikan solusi berupa: melakukan pengembangan perpustakaan dengan membersihkan dan menata ulang ruangan perpustakaan, memberikan bimbingan belajar kepada pelajar di kelurahan Sekargadung, dan memberikan informasi terkait perguruan tinggi yang hanya membutuhkan biaya terjangkau agar mereka dapat meneruskan pendidikan ke jenjang yang lebih tinggi.
\end{abstract}

Kata Kunci: perpustakaan, pendidikan, perguruan tinggi

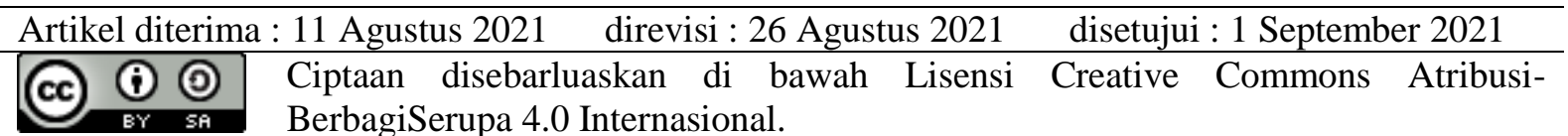




\section{Pendahuluan}

Mahasiswa merupakan generasi penerus bangsa yang dituntut mampu meningkatkan kualitas Sumber Daya Manusia (SDM) dengan cara meningkatkan keterampilan, intelektual, dan melaksanakan pengabdian kepada masyarakat melalui disiplin ilmu. Cara tersebut dilakukan agar mahasiswa dapat menjawab tantangan pada masa kini yang telah memasuki era 5.0 .

Saat ini dunia telah dilanda pandemi covid-19 yang terjadi sejak tahun 2020 silam. Dampak terbesar dari pandemi ini adalah pada dunia pendidikan. Dimana pelaksanaan proses belajar mengajar tidak lagi dilakukan di sekolah melainkan dilakukan di rumah atau daring (dalam jaringan) sesuai Surat Edaran Mendikbud Nomor 4 Tahun 2020 tentang Pelaksanaan Kebijakan Pendidikan dalam Masa Darurat Penyebaran Covid-19.

Kebijakan yang meminta pembelajaran melakukan sistem daring sampai batas waktu yang tidak ditentukan sebagai akibat adanya COVID-19 yang telah memakan banyak korban. Pembelajaran tatap muka secara langsung terpaksa diganti menjadi Kegiatan Belajar Mengajar (KBM) jarak jauh yang berarti menerapkan sistem daring (dalam jaringan). Pembelajaran daring adalah pembelajaran yang menggunakan media interaktif berupa internet dan Learning Manajemen System (LMS) seperti: telepon, Google Meet, Zoom, dan lainnya (Prameswati et al., 2021).

Dengan adanya pembelajaran jarak jauh, peserta didik mau tidak mau akan mengikuti kegiatan belajar mengajar dalam jaringan (daring). Materi pembelajaran yang diberikan oleh pendidik dalam pembelajaran jarak jauh terkadang membuat peserta didik kesulitan dalam menerima materi yang disampaikan. Oleh karena itu, baik orang tua maupun guru dituntut agar lebih kooperatif dalam melakukan pendampingan dan pembimbingan belajar terhadap putra-putrinya.
Kelurahan Sekargadung juga memfasilitasi perpustakaan bagi warga sekitar, akan tetapi peminat baca yang kurang menjadikan perpustakaan seperti tidak terkelola. Apalagi tidak ada pendukung sarana teknologi karena semua masih dikelola dengan manual.

Tidak hanya permasalahan pendidikan dan perpustakaan saja, sektor ekonomi juga dipengaruhi oleh pandemi Covid-19. Banyak masyarakat tidak dapat menyekolahkan putra-putrinya hingga lulus sekolah atau sampai perguruan tinggi lantaran permasalahan ekonomi yang dihadapi.

Dalam memecahkan persoalan di atas, maka adanya program Kuliah Kerja Nyata Dari Rumah (KKN-DR) mahasiswa Universitas PGRI Wiranegara yang merupakan bentuk suatu pengabdian mahasiswa terhadap masyarakat dan menjadi salah satu bagian dari tri dharma perguruan tinggi. Sehingga hal ini melatarbelakangi kegiatan KKN dilakukan di kelurahan Sekargadung guna membantu peserta didik dalam pembelajaran daring pada mata pelajaran bahasa Indonesia dan matematika bagi siswa Sekolah Dasar (SD) bertempat di balai kelurahan Sekargadung.

Serta membantu pengembangan perpustakaan Sekargadung agar tertata lebih baik lagi, dan membantu masyarakat pemuda desa mendapatkan informasi mengenai kuliah dengan biaya terjangkau ke jenjang yang lebih tinggi lagi atau ke perguruan tinggi.

\section{Metode Pelaksanaan}

Dalam pelaksanaan KKN-DR di kelurahan Sekargadung terbagi menjadi tiga kegiatan yaitu: pertama pengembangan perpustakaan desa; kedua memberikan bimbingan belajar kepada pelajar di desa; dan ketiga mensosialisasikan perguruan tinggi Universitas PGRI Wiranegara (UNIWARA) kepada organisasi pemuda desa. Dalam pembagian bidang tersebut, mahasiswa melaksanakan program kegiatan yang telah disesuaikan dengan masalah dan kondisi masyarakat di kelurahan Sekargadung. 
Pengembangan perpustakaan yang ada di kelurahan Sekargadung dengan beberapa cara seperti: pertama meningkatkan kenyamanan bagi para pembaca; kedua mendonasikan buku bacaan; ketiga membuat logo dan media sosial perpustakaan keluarahan Sekargadung.

Memberikan bimbingan belajar kepada pelajar di desa. Dalam hal ini, mahasiswa KKN-DR kelurahan Sekargadung memberikan bimbingan belajar kepada peserta didik kelas 5 SD Negeri Sekargadung dengan materi pelajaran Matematika dan Bahasa Indonesia sesuai dengan panduan AKM yang akan mereka hadapi. Pelaksanaan ini tetap mematuhi protokol kesehatan dan dalam satu kelas hanya terdiri dari $7-10$ orang siswa selama 6 hari.

Mensosialisasikan perguruan tinggi Universitas PGRI Wiranegara Pasuruan kepada organisasi pemuda desa. Mahasiswa KKN-DR kelurahan Sekargadung memberikan informasi terkait perguruan tinggi yang ada di Indonesia dan memperkenalkan Universitas PGRI Wiranegara. Hal ini agar pemuda desa dapat melanjutkan pendidikan yang lebih tinggi lagi dengan informasi perguruan tinggi yang memiliki pembiayaan yang cukup murah.

\section{Hasil dan Pembahasan}

KKN-DR dari Universitas PGRI Wiranegara Pasuruan dilaksanakan pada tanggal 1 Juli s.d1 Agustus 2021 di kelurahan Sekargadung. Dalam kegiatan KKN-DR ini, mahasiswa mengambil kegiatan desa yang berfokus pada 1) Pengembangan Perpustakaan Desa, 2) Memberikan Bimbingan Belajar kepada Pelajar di Desa, dan 3) Mensosialisasikan Perguruan Tinggi dan UNIWARA kepada Organisasi Pemuda Desa.

Kegiatan bertujuan untuk membantu meningkatkan kualitas pendidikan di desa. Seperti yang kita ketahui, tak sedikit penduduk desa yang masih belum sepenuhnya dapat merasakan bangku sekolah atau meneruskan ke jenjang perguruan tinggi karena terhalangnya kondisi ekonomi dan pemenuhan sarana seperti komputer atau laptop yang masih kurang. Pelaksanaan kegiatan KKN-DR dilaksanakan sesuai dengan jadwal yang telah dibuat agar kegiatan dapat terlaksana tepat waktu.

\section{Kegiatan Pertama Pengembangan Perpustakaan}

Perpustakaan mempunyai peran penting dalam mencerdaskan kehidupan bangsa dimana menyediakan informasi bagi seluruh masyarakat. Perpustakaan berada di lingkungan yang kompleks dan selalu berubah seiring perkembangan zaman. Oleh karena itu, pengembangan perpustakaan perlu dilakukan dengan tujuan untuk meningkatkan minat masyarakat terhadap perpustakaan serta meningkatkan kualitas layanan pepustakaan sehingga visi dan misi yang ditentukan dapat tercapai

Pengembangan perpustakaan kelurahan Sekargadung dilaksanakan pada tanggal 18 Juli 2021 dan 1 Agustus 2021. Sebelum hari pelaksanaan, Kamis, $15 \mathrm{Juli}$ 2021 mahasiswa KKN-DR kelurahan Sekargadung melakukan observasi dan berdiskusi dengan pengelola perpustakaan kelurahan Sekargadung. Dari diskusi tersebut menghasilkan kesepakatan untuk melakukan upaya-upaya pengembangan perpustakaan, diantaranya: 1) Melakukan penataan ruang perpustakaan, 2) Menambah koleksi buku di perpustakaan, dan 3) Pembuatan logo dan akun instagram perpustakaan.

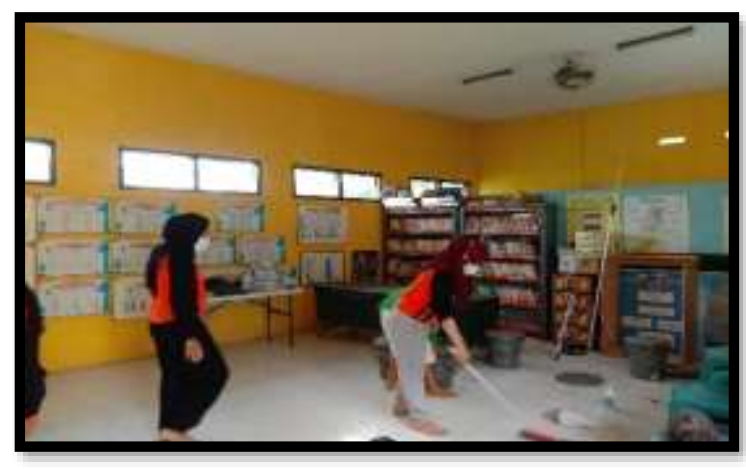

Gambar 1. Penataan ruang perpustakaan 
Penataan ruang perpustakaan dilaksanakan pada hari Minggu, 18 Juli 2021 pukul 08.00 WIB sampai selesai. Dengan tertatanya ruang perpustakaan yang memperhatikan lokasi, aspek penataan ruang, dan penataan perlengkapan maka terciptanya suasana yang aman, nyaman dan menyenangkan bagi pengunjung serta memudahkan petugas perpustakaan dalam melakukan perawatan.

Mahasiswa KKN-DR kelurahan Sekargadung membuka donasi buku guna menambah koleksi buku di Perpustakaan Kelurahan Sekargadung. Koleksi buku perpustakaan dapat dikategorikan baik karena memenuhi selera, keinginan dan kebutuhan masyarakat.

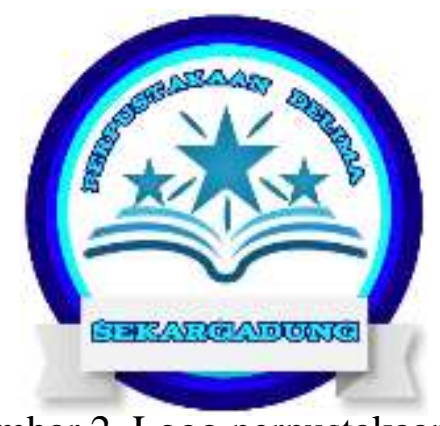

Gambar 2. Logo perpustakaan

Pembuatan logo dan akun instagram perpustakaan kelurahan Sekargadung dilaksanakan pada tanggal 1 Agustus 2021. Logo merupakan bentuk penggambaran maupun identitas. Dengan adanya logo dapat menyampaikan peran penting dari perpustakaan kelurahan Sekargadung. Kemudian, adanya akun instagram perpustakaan kelurahan Sekargadung dapat digunakan sebagai promosi agar keberadaan perpustakaan kelurahan Sekargadung diketahui oleh seluruh masyarakat. Dengan akun instagram yang dimiliki, perpustakaan kelurahan Sekargadung dapat membagikan informasi tentang jam pelayanan, foto-foto atau video koleksi buku maupun kegiatan yang dimiliki perpustakaan.

\section{Kegiatan Kedua Bimbingan Belajar}

Pandemi Covid-19 sampai saat ini masih melanda seluruh dunia, termasuk Indonesia. Selama pandemi, kegiatan belajar mengajar dilakukan secara daring untuk menghindari dan mencegah penyebaran Covid-19. Namun cukup banyak siswa kesulitan dalam menerima dan memahami pembelajaran yang diberikan, termasuk pada anak-anak sekolah dasar di kelurahan Sekargadung. Untuk itu mahasiswa KKN-DR mengadakan bimbingan belajar untuk membantu anak-anak yang kesulitan memahami materi.

Pada hari Selasa, 13 Juli 2021 mahasiswa KKN-DR melakukan diskusi dengan kepala sekolah SDN Sekargadung mengenai pelaksanaan bimbingan belajar. Sasaran bimbingan belajar yaitu siswa kelas 5 SDN Sekargadung yang memiliki kemampuan rendah dalam memahami pembelajaran di sekolah. Arahan untuk memberikan bimbingan belajar telah didiskusikan dengan Kepala Kelurahan Sekargadung dikarenakan di Sekargadung hanya terdapat 1 sekolah yaitu SD Sekargadung.

Kegiatan bimbingan belajar dilaksanakan pada tanggal 22-24 Juli 2021 dan 26-28 Juli 2021 mulai pukul 07.30 - 09.30 WIB dengan pembatasan 10 siswa tiap harinya dan tetap mematuhi protokol kesehatan. Siswa kelas 5 SDN mendapatkan bimbingan belajar untuk mata pelajaran Bahasa Indonesia dan Matematika.

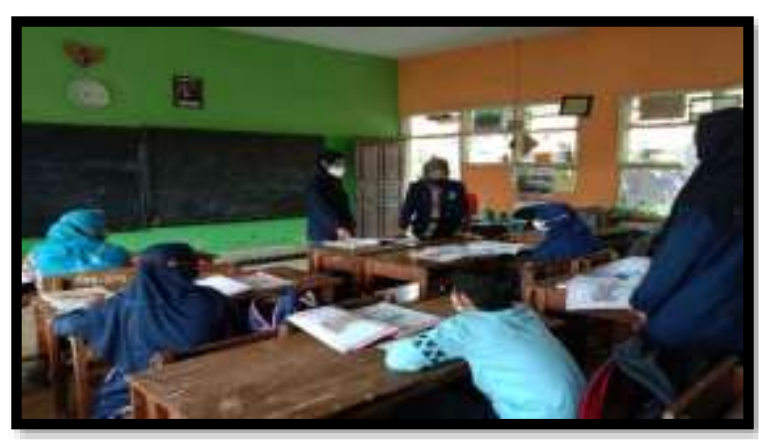

Gambar 3. Kegiatan Bimbingan Belajar

Meskipun tidak semua siswa hadir tetapi tidak mengurangi rasa semangat dalam pelaksaan bimbingan belajar. Siswa kelas 5 SDN Sekargadung memperhatikan dengan saksama setiap materi yang diberikan. Pembelajaran juga diselingi 
dalam bentuk game/permainan untuk menciptakan iklim belajar aktif, menarik dan tetap kondusif. Suasana belajar yang kondusif ini pada akhirnya mempermudah pemahaman materi pada siswa, sehingga diharapkan hasil belajar pun meningkat.

\section{Kegiatan Ketiga Sosialisasi Pendidikan Tinggi UNIWARA}

Kegiatan mensosialisasikan kampus merupakan strategi dari universitas yang digunakan untuk memperkenalkan kampus kepada masyarakat luas, khususnya pada para remaja yang baru lulus SMA dan diharapkan mendapatkan hasil dari kegiatan ini yaitu adanya para remaja yang mendaftar untuk menjadi mahasiswa baru.

Sebelum mengadakan sosialisasi kampus, pastinya kita harus menganalisis terlebih dahulu kebutuhan apa yang diperlukan oleh para remaja di sekitar lokasi, seperti: menganalisis situasi internal dan eksternal, penetapan tujuan, pemilihan dan penetapan strategi, komponen layanan pendidikan, biaya pendidikan, blokasi, dan promosi. Hal ini dilakukan agar tujuan dan materi yang disampaikan sangat berguna oleh warga sekitar.

Sosialisasi yang dilakukan bukan hanya mensosialisasikan peran dari pendidikan, namun output apa yang didapat setelah melaksanakan pendidikan tinggi, seperti penempatan kerja yang layak (Carnoy, 1974).

Dengan adanya sosialisasi kampus yang dilakukan, kemungkinan besar akan menggugah para remaja untuk bisa malanjutkan jenjang pendidikan yang lebih tinggi agar tingkat pengangguran dapat lebih di tahan. Tak hanya dengan kuliah, para remaja juga bisa melaksanakan kerja dengan kuliah (Callaway, 1971).

Banyaknya anak usia remaja tidak melanjutkan pendidikan tinggi, lebih sering ditemukan yaitu kesulitan ekonomi. Hal ini dikarenakan tingginya biaya yang harus dikeluarkan oleh masyarakat, sehingga masyarakat diibaratkan "membeli" pendidikan bagi anaknya. Tak hanya itu, ada tiga bentuk kesulitan yang melekat pada aktivitas pendidikan, yaitu produksi pendidikan, identifikasi transaktor ekonomi yang berhubungan dengan pendidikan, dan kenyataan bahwa pendidikan mempunyai sifat-sifat pelayanan umum (Hallak, 1967).

Dengan adanya sosialisasi ini dapat membantu adik-adik para remaja untuk bisa mendapatkan beasiswa kuliah agar mereka dapat melanjutkan ke pendidikan yang lebih tinggi, mengingat sangat penting bari para remaja memiliki pendidikan tinggi.

Sosialisasi dilaksanakan pada hari Sabtu, 31 Juli 2021 pukul 09.00-10.00 WIB. Sosialisasi dilaksanakan di SDN Sekargadung. Sasaran Tim KKN-DR Kelurahan Sekargadung adalah Organisasi Pemuda Desa yaitu Organisai Forum Anak Cab. Sekargadung dan IPPNU Cab. Sekargadung. Sosialisiasi dihadiri oleh 14 orang dan tetap mematuhi protokol kesehatan seperti pada gambar 4 di bawah.

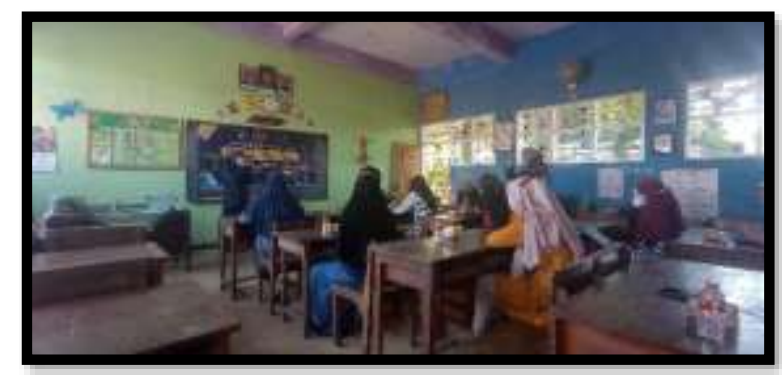

Gambar 4. Sosialisasi Perguruan Tinggi

Sosialisasi bertujuan untuk memberikan pengetahuan dan pemahaman mengenai pentingnya pendidikan, menumbuhkan kesadaran dan meningkatkan motivasi siswa SMA agar melanjutkan pendidikan hingga perguruan tinggi.

\section{Simpulan}

\section{Penutup}

Semua program dapat terlaksana dengan baik dan lancar walaupun ada beberapa kendala, namun hal tersebut dapat diatasi. Kegiatan program kelompok ini dilaksanakan pada pagi hari, siang hari. Dengan terlaksananya program-program 
tersebut diharapkan dapat bermanfaat bagi masyarakat kelurahan Sekargadung.

Keberhasilan program-program pada akhirnya akan memberikan manfaat yang saling menguntungkan antara mahasiswa dan masyarakat. Sisi positif bagi mahasiswa adalah meningkatkan kepe-dulian terhadap lingkungan sekitar baik di masyarakat dan memperluas cakrawala pemikiran serta dapat melatih keaktifan mahasiswa dalam hidup bermasyarakat.

Mahasiswa KKN dalam belajar bersosialisasi dengan warga masyarakat, belajar bersikap dan beradaptasi dengan orang lain sesuai dengan norma-norma yang berlaku. Di samping itu, peran serta masyarakat juga mendukung dalam kelancaran pelaksanaan program KKN

Saran

Bagi masyarakat kelurahan Sekargadung dapat menyempurnakan program mahasiswa KKN yang belum sesuai seperti perpustakaan dan melanjutkan program-program yang berkelanjutan. Program-program yang telah dilaksanakan mahasiswa KKN semoga dapat diteruskan dan dikembangkan serta dimanfaatkan untuk kepentingan masyarakat setempat.

\section{Daftar Pustaka}

Callaway, A. (1971). "Educational planning and unemployed youth" (Issue 14). Unesco, International Institute for Educational Planning.

Carnoy, M. (1974). "Education as cultural imperialism". Longman.

Hallak, J. (1967). "Educational Costs and Productivity".

Prameswati, L. N., Nafi'ah, I. M., \& Purwono, P. Y. (2021). "Program Pendampingan Pembelajaran Bagi Siswa Sekolah Dasar Kota Kediri di Masa Pandemi". Jurnal Pasopati: Pengabdian Masyarakat Dan Inovasi Pengembangan Teknologi, 3(1), 1824. 